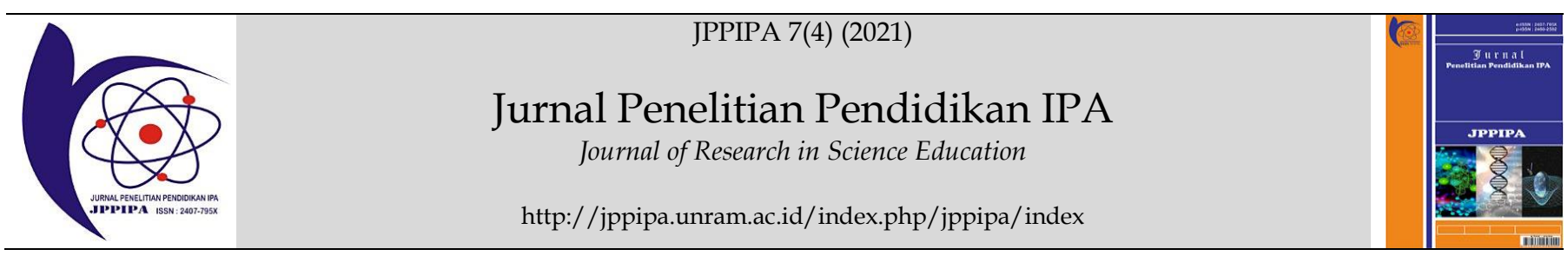

\title{
Optimizing the Use of Physics KITs that are integrated with the Scientific Context and Its Impact for Physics Teachers
}

\author{
Renol Afrizon ${ }^{1}$, Hidayati ${ }^{1}$, Letmi Dwiridal ${ }^{1}$, Najmil Khaira ${ }^{1}$ \\ ${ }^{1}$ Department of Physics, Faculty of Mathematics and Natural Sciences, Universitas Negeri Padang, Jl. Prof Hamka, Padang 25131, Indonesia
}

DOI: $\underline{10.29303 / \text { jppipa.v7i4.1042 }}$

\section{Article Info}

Received: September 20th, 2021

Revised: October $15^{\text {th }}, 2021$

Accepted: October 26th, 2021

\begin{abstract}
The background of this research is the lack of competence of physics teachers in using physics KIT. This research was conducted with the hope that there will be an increase in the competence of senior high school physics teachers in West Pasaman in using the physics KIT. This research was conducted with a quasi-experimental design and one group pretest-posttest. This study has a population of all physics teachers who join physics teachers group in West Pasaman Regency. The sample was taken by using simple random sampling technique, selecting 22 teachers as representatives of the physics teachers group in West Pasaman Regency. The results showed an increase in teachers' competence in using the physics KIT after mentoring the use of the physics KIT. The increase in teacher competence can be described through the value of again, the $\mathrm{N}$-gain value obtained is 0.33 (moderate). This means that the teacher's competence in using the physics KIT can increase after mentoring the use of the physics KIT.
\end{abstract}

Keywords: Teacher Competencies, Physics KIT, Scientific Context

Citation: $\quad$ Afrizon, R., Hidayati, H., Dwiridal, L. ., \& Khaira, N. (2021). Optimizing the Use of Physics KITs that are integrated with the Scientific Context and Its Impact for Physics Teachers. Jurnal Penelitian Pendidikan IPA, 7(4). https://doi.org/10.29303/ippipa.v7i4.1042

\section{Introduction}

Natural science has several branches: physics, which deals with matter and its interactions (Sumardi 2002). Physics can also be called science that studies natural phenomena. Physics can also be studied through observations, experiments, and theories, where the results are made in the form of facts, laws, principles, concepts, and theories (Sari et al., 2018).

Physics can be taught in schools through a learning process structured in such a way that it becomes an activity that can support the learning process of children. The learning process is an activity that is intentionally designed by the teacher, where the teacher will teach and students learn. The learning process can be said to be interactive when there is twoway communication, namely between the teacher and the student. To obtain an interactive learning process, creative teachers are needed in designing lesson plans, so that they can increase student interest.

Physics is a mandatory field of study for the Mathematics and Science specialization that requires students' critical thinking skills in solving problems related to natural phenomena. The physics learning process can be created through several activities, namely observation, practicum, and problem solving, to interpret various natural phenomena that exist in daily life (Usmeldi, 2016). Observation activities are carried out so that students get the opportunity to collect data, information, and facts related to the required learning material. Practical activities are carried out so that students can find concepts and principles independently according to the required learning material. In learning physics, students are required to be able to think scientifically based on the scientific method, because learning physics cannot be separated from observation and practicum activities, where these two activities require students to have 
scientific thinking skills.

Practical activities are a learning process that can be experienced directly by students, by following each process and step as well as observing and drawing conclusions from the objects and circumstances of the material being studied. Practicum is a series of activities that allow students to practice a skill they possess (Maulida et al, 2017). Physics is grouped in physical knowledge, where direct contact is needed with the things you want to learn in the formation of knowledge and studying physics, therefore in physics learning practicum activities are needed (Subekti et al, 2016). However, in reality, practicum activities are still very rarely implemented in schools, so that learning is not student-centered.

One of the objectives of learning physics is to be able to demonstrate scientific behavior (curious, objective, honest, thorough, thorough, diligent, tenacious, careful, responsible, open, critical, creative, innovative, and cares about the environment) in daily activities as a form of implementation of scientific attitude in conducting experiments and discussing (Ministry of Education and Culture, 2014). To achieve this goal, practicum activities should have been carried out in every school. Regulation of the Minister of Education and Culture of the Republic of Indonesia Number 20 of 2016 concerning Competency Standards for Graduates of Primary and Secondary Education Units that every graduate of primary and secondary education units has competence in three dimensions, namely attitudes, knowledge, and skills (Minister of Education and Culture, 2016). In this case, the role of the laboratory is very important as part of the physics learning process to achieve the dimensions of skills. In addition, the availability of practicum equipment in schools is very important to achieve the competency standard. One of the solutions provided by the government in an effort to achieve these standards is to provide physics laboratory equipment, in the form of: KIT mechanics, KIT thermodynamics and waves, KIT optics, as well as KIT electricity and magnetism.

The provision of physics laboratory equipment to schools by the government has not been able to meet the needs for practical implementation in the field. Teachers rarely use the physics KIT that has been provided, this is due to the teacher's inadequate ability to use the physics KIT. The implementation of practical activities in the field is still very minimal, where one of the reasons is the limited knowledge of teachers about how to use laboratory equipment. (Jamaluddin et al, 2015). The infrequent implementation of practicum activities in schools also has an impact on students' low ability to understand physics lessons.

In the 21st century, scientific and technological developments occur so rapidly that it requires every human being to adapt in all aspects of life, one of the efforts that can be made in dealing with this challenge is to master scientific literacy. Scientific literacy includes scientific knowledge and the use of that knowledge to analyze questions, discover new knowledge to explain related scientific phenomena (Thomson et al, 2013). A person who has scientific literacy can use his scientific knowledge to solve the problems he faces. Scientific literacy has three main dimensions: the scientific process, scientific content, and the context of the scientific application (Eivers et al, 2016). Scientific content is scientific concepts that are needed to understand natural phenomena. The scientific process is the process of answering questions or solving problems encountered. The context of scientific application is a life situation that is related to the application of science. As for examples of scientific contexts in learning physics, such as the study of physics in the Minangkabau traditional building (Renol Afrizon et al, 2017) and traditional musical instruments (Renol Afrizon et al, 2020). Contexts for the PISA scientific literacy assessment in Figure 1.

\begin{tabular}{|c|c|c|c|}
\hline & $\begin{array}{l}\text { Personal } \\
\text { (self, family and peer groups) }\end{array}$ & $\begin{array}{l}\text { Social } \\
\text { (the community) }\end{array}$ & $\begin{array}{l}\text { Global } \\
\text { (life across the world) }\end{array}$ \\
\hline Health & $\begin{array}{l}\text { maintenance of health, } \\
\text { accidents, nutrition }\end{array}$ & $\begin{array}{l}\text { control of disease, social } \\
\text { transmission, food choices, } \\
\text { community health }\end{array}$ & $\begin{array}{l}\text { epidemics, spread of infectious } \\
\text { diseases }\end{array}$ \\
\hline $\begin{array}{l}\text { Natural } \\
\text { resources }\end{array}$ & $\begin{array}{l}\text { personal consumption of } \\
\text { materials and energy }\end{array}$ & $\begin{array}{l}\text { maintenance of human } \\
\text { populations, quality of life, } \\
\text { security, production and } \\
\text { distribution of food, energy } \\
\text { supply }\end{array}$ & $\begin{array}{l}\text { renewable and non-renewable } \\
\text { energy sources, natural } \\
\text { systems, population growth, } \\
\text { sustainable uses of species }\end{array}$ \\
\hline Environment & $\begin{array}{l}\text { environmentally friendly } \\
\text { behaviour, use and disposal of } \\
\text { materials }\end{array}$ & $\begin{array}{l}\text { population distribution, } \\
\text { disposal of waste, } \\
\text { environmental impact, local } \\
\text { weather }\end{array}$ & $\begin{array}{l}\text { biodiversity, ecological } \\
\text { sustainability, control of } \\
\text { pollution, production and loss } \\
\text { of soil }\end{array}$ \\
\hline Hazard & $\begin{array}{l}\text { natural and human-induced } \\
\text { decisions about housing }\end{array}$ & $\begin{array}{l}\text { rapid changes (earthquakes, } \\
\text { severe weather), slow and } \\
\text { progressive changes (coastal } \\
\text { erosion, sedimentation), risk } \\
\text { assessment }\end{array}$ & $\begin{array}{l}\text { climate change, impact of } \\
\text { modern warfare }\end{array}$ \\
\hline $\begin{array}{l}\text { Frontiers for } \\
\text { science and } \\
\text { technology }\end{array}$ & $\begin{array}{l}\text { interest in science's } \\
\text { explanations of natural } \\
\text { phenomena, science-based } \\
\text { hobbies, sport and leisure, } \\
\text { music and personal technology }\end{array}$ & $\begin{array}{l}\text { new materials, devices } \\
\text { and processes, genetic } \\
\text { modification, weapons } \\
\text { technology, transport }\end{array}$ & $\begin{array}{l}\text { extinction of species, } \\
\text { exploration of space, origin and } \\
\text { structure of the universe }\end{array}$ \\
\hline
\end{tabular}

(Source: Thomson et al, 2013)

Figure 1. Contexts for the PISA scientific literacy assessment

Scientific literacy of students in Indonesia can be classified in the low category according to PISA 2015 results (Fa'idah, $\mathrm{H}$ et al, 2019). This problem becomes a new challenge for a teacher as a teaching force to improve scientific literacy among students. In order to improve scientific literacy in students, teachers have a very important role (Al Sultan et al, 2021).

Physics learning will be more interesting if the learning process is carried out utilizing the surrounding environment as a learning resource, so that there is a relationship between the material studied and daily activities (Susanti et al, 2019). KIT that is integrated with a scientific context will help teachers 
produce more interesting and meaningful learning, where students not only understand but can apply their knowledge in a situation they experience.

Practical activities using KIT integrated with scientific context can be done if the teacher has sufficient knowledge about the use of KIT and the scientific context. The use of KIT which is still rare and knowledge of the scientific context in physics learning is still minimal, which is the driving force for researchers to optimize the use of KIT and understand the scientific context in physics learning. Based on these problems, solutions were given in the form of training on the use of KIT and briefing on the preparation of integrated Physics worksheets in scientific contexts. Through this activity, it is hoped that the teacher's ability and knowledge in using KIT can be better to support the physics learning process in the classroom.

KIT is laboratory equipment that is used to support the implementation of practicum. Science KIT (physics) is a scientific practicum tool that is stored with a practical packaging system so that it can help schools have standard and highly efficient equipment (Sasmita 2017). The use of KIT as a physics learning medium can help students find their own concepts by proving existing theories. Besides that, the use of KIT can make students more motivated because they are directly involved in the learning process. The existence of practicum activities will make physics learning more interesting and fun for students.

In an effort to make physics learning interesting and meaningful for students, the use of integrated KIT in scientific context has an important role. This requires teachers to have sufficient ability and understanding of using KIT. Based on this background, research activities on mentoring the use of integrated KIT in scientific context were carried out in order to improve teacher competence in using KIT physics through direct mentoring activities.

\section{Method}

This type of research is a quasi-experimental research (quasi-experimental) and uses a quantitative approach. Quasi-experimental research is a variable control research, in a quasi-experimental controlled variable only one, namely the most dominant variable (Herman 2019). Research with a quantitative approach is research using numbers, ranging from data collection, interpretation of statistical data and the appearance of results (S.Siyoto, 2015).

The research was designed using a one group pretest-posttest design (S.Siyoto, 2015). Pretest is given to teachers before mentoring is given, as a test to determine the teacher's initial competence. Posttest is given after mentoring is carried out, to determine the final competence of the teacher. The results of the two tests will be analyzed to determine the improvement of teacher competence regarding the use of physics KIT. This research was conducted in 4 stages, namely material debriefing, practice the use of KIT, independent tasks, evaluation as shown in Figure 2.

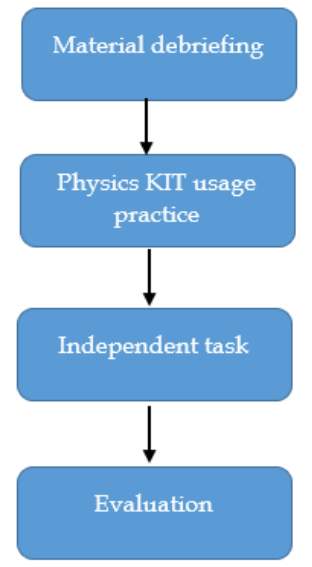

Figure 2. Research Flowchart

In the tests carried out, a test instrument was used to determine teacher competence in the form of 20 pretest questions and 20 posttest questions. This question is made with the same discussion. The population used is physics teachers who are members of the West Pasaman Physics teacher group. Simple random sampling technique was used to select 22 teachers to represent all high schools in West Pasaman district.

From this study, data were obtained in the form of the competence of physics teachers related to knowledge of the scientific context and physics KIT and their use. Data analysis using the SPSS version 28.0.0.0 was used to see the difference in the average value before being given treatment and after being given treatment by using the paired $\mathrm{t}$-test. In addition, the $\mathrm{N}$ gain test was also conducted to see the increase in teacher competence. The criteria and interpretation for paired $\mathrm{t}$-test and $\mathrm{N}$-gain test can be seen in Tables 1 and 2.

Table 1. Criteria and interpretation of test of similarities between two samples

\begin{tabular}{lllll}
\hline No & & Statistic Test & Criteria & Interpretation \\
\hline 1 & Test of Normality & Saphiro-Wilk Statistic & Sig value $>0.05$ & Normal \\
2 & Tests of Homogeneity of Variances & Levene Statistic & Sig value $>0.05$ & Homogeneous \\
3 & Test of similarities between two samples & Paired Samples t-Test & Sig value $<0.05$ & Ho refused \\
\hline
\end{tabular}


Table 2. Interpretation of the normalized gain scores

\begin{tabular}{lll}
\hline No & $\langle g\rangle$ & Interpretation \\
\hline 1 & $(<\mathrm{g}>)<0.30$ & Low \\
2 & $0.30 \leq(<\mathrm{g}>)<0.70$ & Moderate \\
3 & $(<\mathrm{g}>) \geq 0.70$ & High \\
\hline
\end{tabular}

Hake (1998)

\section{Result and Discussion}

From the research conducted, it was obtained data in the form of pretest and posttest results for physics teachers who participated in mentoring activities for using integrated KIT in scientific contexts in West Pasaman. The results of the study show how far the competence of physics teachers has increased in using KIT to support the learning process. The data obtained were analyzed statistically to compare the teacher's competence after and before being given treatment. The results of the pretest and posttest statistical analysis can be seen in Table 3 . The pretest is the previous competency and is coded " 1 ". Posttest is a competency after being given mentoring and given the code "2".

Table 3. Results of Pretest and Posttest Statistical Descriptives Analysis

\begin{tabular}{|c|c|c|c|c|}
\hline & \multicolumn{3}{|l|}{ Test } & \multirow{2}{*}{$\frac{\text { Statistic }}{53.4091}$} \\
\hline Teacher & 1.00 & Mean & & \\
\hline Compe- & & 95\% Confidence & Lower Bound & 46.5887 \\
\hline tence & & Interval for Mean & Upper Bound & 60.2295 \\
\hline & & 5\% Trimmed Mean & & 54.2929 \\
\hline & & Median & & 57.5000 \\
\hline & & Variance & & 236.634 \\
\hline & & Std. Deviation & & 15.3829 \\
\hline & & Minimum & & 10.00 \\
\hline & & Maximum & & 80.00 \\
\hline & & Range & & 70.00 \\
\hline & & Interquartile Range & & 21.25 \\
\hline & & Skewness & & -1.084 \\
\hline & & Kurtosis & & 1.833 \\
\hline & 2.00 & Mean & & 68.6364 \\
\hline & & 95\% Confidence & Lower Bound & 62.1035 \\
\hline & & Interval for Mean & Upper Bound & 75.1692 \\
\hline & & 5\% Trimmed Mean & & 68.7626 \\
\hline & & Median & & 70.0000 \\
\hline & & Variance & & 217.100 \\
\hline & & Std. Deviation & & 14.7343 \\
\hline & & Minimum & & 35.00 \\
\hline & & Maximum & & 100.00 \\
\hline & & Range & & 65.00 \\
\hline & & Interquartile Range & & 15.00 \\
\hline & & Skewness & & -0.160 \\
\hline & & Kurtosis & & 0.760 \\
\hline
\end{tabular}

From the results of statistical analysis on Table 3, it can be seen that there is a difference between the minimum and maximum values in the pretest and posttest. For the minimum value there was an increase from 10 to 35 . For the maximum value there was an increase from 80-100. Prior to the treatment, the average value obtained was 53.41 and increased to 68.64 after the treatment. In determining the characteristics of the data group can be used homogeneity test and normality test. The following table 4 is the result of the normality test that has been done.

Table 4. Tests of Normality

\begin{tabular}{lllll}
\hline & Test & \multicolumn{3}{l}{ Shapiro-Wilk } \\
& & Statistic & df & Sig. \\
\hline Teacher Competence & 1.00 & 0.922 & 22 & 0.084 \\
& 2.00 & 0.957 & 22 & 0.436 \\
\hline
\end{tabular}

From the normality test with Shapiro-Wilk on table 4 , the significance value for the pretest was 0.084 and for the post-test was 0.436 . From the above value, it can be seen that the significance value is greater than 0.05 , so the pretest and posttest results are said to be normally distributed. Whereas, for the results of the homogeneity test of the pretest and posttest data, it can be seen in Table 5. From the homogeneity test on table 5 , it was found that the significance value $(0.771)$ was more than 0.05 . It means the pretest and posttest data were said to be homogeneous. After the data obtained are said to be normal and homogeneous, the next step is the paired samples $t$-Test to see the difference between the pretest and posttest scores. It is described in Table 6.

Table 5. Results of Tests of Homogeneity of Variances

\begin{tabular}{|c|c|c|c|c|c|}
\hline & & $\begin{array}{l}\text { Levene } \\
\text { Statistic }\end{array}$ & df1 & df2 & Sig. \\
\hline \multirow{8}{*}{$\begin{array}{l}\text { Teacher } \\
\text { Competence }\end{array}$} & Based on & 0.086 & 1 & 42 & 0.771 \\
\hline & Mean & & & & \\
\hline & Based on & 0.045 & 1 & 42 & 0.834 \\
\hline & Median & & & & \\
\hline & Based on & 0.045 & 1 & 41.691 & 0.834 \\
\hline & $\begin{array}{l}\text { Median and } \\
\text { with }\end{array}$ & & & & \\
\hline & adjusted df & 0046 & 1 & 42 & 0831 \\
\hline & $\begin{array}{l}\text { trimmed } \\
\text { mean }\end{array}$ & 0.070 & 1 & $T 2$ & 0.001 \\
\hline
\end{tabular}


Table 6. Paired Samples t-Test Result

\begin{tabular}{|c|c|c|c|c|c|c|c|c|c|c|}
\hline & & Paired I & ferences & & & & & & Significa & \\
\hline & & & & Std. Error & $\begin{array}{l}95 \% \mathrm{Co} \\
\text { the Diff }\end{array}$ & ce Interval of & & & One- & \\
\hline & & Mean & Deviation & Mean & Lower & Upper & $\mathrm{t}$ & df & Sided $p$ & Sided $\mathrm{p}$ \\
\hline Pair 1 & pretest - postest & -15.227 & 26.299 & 5.607 & -26.887 & -3.567 & -2.716 & 21 & 0.006 & 0.013 \\
\hline
\end{tabular}

Table 6 shows that the results of the t-test with a $95 \%$ confidence level, the significance value $(0.006)$ obtained is smaller than 0.05 , so there is a difference between the pretest and posttest values. The $\mathrm{N}$-gain test needs to be carried out to determine the increase in teacher competence after being provided with assistance as shown in Table 7.

Table 7. N-gain test result

\begin{tabular}{llll}
\hline $\begin{array}{l}\text { Pretest } \\
\text { average }\end{array}$ & $\begin{array}{l}\text { Postest } \\
\text { average }\end{array}$ & N-Gain & Criteria \\
\hline $\mathbf{5 3 . 4 1}$ & 68.63 & 0.33 & moderate \\
\hline
\end{tabular}

From the results on Table 7, it can be seen that there is an increase in teacher competence after mentoring the use of KIT physics. The value of the Ngain test obtained is 0.33 , which means the increase in teacher competence after treatment is in the moderate category. The implementation of mentoring activities using demonstrations and hands-on practice has been able to increase the basic knowledge of teachers (Renol Afrizon et al, 2020).

This research is also in line with the research conducted by Syaiful et al regarding the scientific approach-based physics KIT assistance training at SMA Negeri 1 Bengkulu Tengah Regency which stated that there was an increase in the ability of teachers to use the physics KIT available at school (Rochman et al. 2021).

The existence of mentoring in the use of physics KIT for high school physics teachers in West Pasaman district can improve teacher competence in using KIT so that it can be implemented later in the learning process. In addition, mentoring in the use of KIT can also help teachers create more interesting learning, by linking natural phenomena that occur around us with physics materials.

Practicum is an activity that is very important in learning physics. Teachers need to have the ability to use the physics KIT to support practicum activities. This makes mentoring activities using the physics KIT needed by teachers so that after the mentoring activities are carried out, it can be seen that the teacher's ability to use physics KIT is seen.

In addition, physics KIT is a learning media provided by the government, therefore in general every school has a physics KIT. However, due to the limited ability of the teacher to use it, the physics KIT is only used as a display in the laboratory. This can be an encouragement for teachers to participate in mentoring the use of physics KIT with enthusiasm.

Improving the quality of support is very important in obtaining superior learning. One of the supporting learning is the teacher (Rochman et al, 2021). Mentoring in the use of physics KIT can improve teacher competence, and teachers can implement it in the field, so that students will also experience an increase in competence, especially in the use of physics KIT.

\section{Conclusion}

Mentoring in the use of the physics KIT integrated scientific literacy for physics teachers can improve the teacher's competence in using the physics KIT so that they can carry out practical activities well as one of the most important activities in physics learning. The increase in teacher competence can be seen from the difference in the average values of the pretest and posttest. The improvement of teacher competence is in the moderate category.

\section{Acknowledgment}

The authors would like to thank Lembaga Penelitian dan Pengabdian Masyarakat Universitas Negeri Padang for funding this work with a contract number 1283/UN35.13/PM/2021.

\section{References}

Al Sultan, A., Henson, H., \& Lickteig, D. (2021). Assessing preservice elementary teachers' conceptual understanding of scientific literacy. Teaching and Teacher Education, 102, 103327. doi: https://doi.org/10.1016/j.tate.2021.103327

Eivers, E., \& Kennedy, D. (2016). the Pisa Assessment of Scientific Literacy. 37(August), 101-119.

Fa'idah, R., Koes H, S., \& Mahanal, S. (2019). Pengaruh Model Pembelajaran Inkuiri Terbimbing terhadap Literasi Sains Siswa Kelas V SD. Jurnal Pendidikan: Teori, Penelitian, dan Pengembangan, 4(12), 1704-1709. doi:http://dx.doi.org/10.17977/jptpp.v4i12.1309 6. [Indonesian] 
Herman, I. (2019). Metodologi Penelitian Pendidikan ( Kualitatif, Kuantitatif dan Mixed Method ). Hidayatul Quran Kuningan. [Indonesian]

Jamaluddin, J., Kade, A., \& Nurjannah, N. (2015). Analisis Pelaksanaan Praktikum Menggunakan Kit Ipa Fisika Di Smp Se-Kecamatan Sojol Kabupaten Donggala. JPFT (Jurnal Pendidikan Fisika Tadulako Online), 3(1), 6. https://doi.org/10.22487/j25805924.2015.v3.i1.2 $\underline{368}$ [Indonesian]

kemendikbud. (2014). Kurikulum 2013 Pedoman Guru Mata Pelajaran Fisika untuk : Sekolah Menengah Atas (SMA)/Madrasah Aliyah (MA). In Badan Penelitian dan Pengembangan Pusat Kurikulum dan Perbukuan (Vol. 53, Issue 9). [Indonesian]

Maulida, D. R., \& Kusumaningtyas, D. A. (2017). Efektivitas Kegiatan Praktikum terhadap Hasil Belajar Fisika Kelas X pada Materi Asas Black di SMA Muhammadiyah 4 Yogyakarta Tahun Ajaran 2015/2016. Jurnal Penelitian $\mathcal{E}$ Pengembangan Pendidikan Fisika, 3(1), 43. https://doi.org/10.21009/1.03106 [Indonesian]

Rochman, S., ., N., Sakti, I., \& Yanuar Zukmadini, A. (2021). Pelatihan Asistensi Kit Fisika Berbasis Scientific Approach Untuk Siswa Di Sman 1 Kabupaten Bengkulu Tengah. Abdi Dosen : Jurnal Pengabdian Pada Masyarakat, 5(1), 168-177. doi: https://doi.org/10.32832/abdidos.v5i1.995 [Indonesian]

S.Siyoto, M. A. S. (2015). Dasar Metodologi Penelitian. Literasi Media Publishing. [Indonesian]

Sari, N., \& Sunarno, W. (2018). Analisis Motivasi Belajar Siswa dalam Pembelajaran Fisika Sekolah Menengah. Jurnal Pendidikan Dan Kebudayaan, 3(1). $\quad$ https://doi.org/10.24832/jpnk.v3i1.591 [Indonesian]

Sasmita, P. R. (2017). Penerapan Metode Inkuiri Terbimbing Menggunakan Media KIT Fisika: Upaya Meningkatkan Aktivitas dan Hasil Belajar Fisika Siswa. Jurnal Ilmiah Pendidikan Fisika AlBiruni, 6(1), 95-102. https://doi.org/10.24042/jpifalbiruni.v6i1.599 [Indonesian]

Subekti, Y., \& Ariswan, A. (2016). Pembelajaran fisika dengan metode eksperimen untuk meningkatkan hasil belajar kognitif dan keterampilan proses sains. Jurnal Inovasi Pendidikan IPA, 2(2), 252. https://doi.org/10.21831/jipi.v2i2.6278 [Indonesian]

Sumardi, Y. (2016). Penggunaan Microsoft Excel Dalam Analisis Data Eksperimen Pada Pembelajaran Fisika. Cakrawala Pendidikan, 2(2). doi:https://doi.org/10.21831/cp.v2i2.8759 [Indonesian]
Susanti, Asyhari, A., \& Firdaos, R. (2019). Efektivitas LKPD Terintegrasi Nilai Islami Pada Kemampuan Literasi Sains Effectivity of Lkpd Integrated Islamic Value on Problem-Based Learning To Improve Scientific Literacy. Indonesian Journal of Science and Mathematics Education, 02(1), 64-78. doi: https://doi.org/10.24042/ijsme.v2i1.3987 [Indonesian]

Thomson, S., Hillman, K., \& Lisa De Bortoli. (2013). Programme for International Student Assessment: A Teacher's Guide to PISA Scientific Literacy.

Usmeldi, U. (2016). Pengembangan Modul Pembelajaran Fisika Berbasis Riset dengan Pendekatan Scientific untuk Meningkatkan Literasi Sains Peserta Didik. Jurnal Penelitian $\mathcal{E}$ Pengembangan Pendidikan Fisika, 2(1), 1 - 8. https://doi.org/10.21009/1.02101. [Indonesian] 